\title{
14
}

\section{Council of Europe Climate Law Standards and Perspectives}

Agata Rogalska-Piechota

\section{Abstract}

The Council of Europe (CoE) is an organisation which covers virtually the entire European continent and is anchored in the three pillars (or common values) - human rights, democracy, and the rule of law. It is famous for its developments regarding human rights protection and the promotion of democratic standards, and is focused mainly on actions aiming to protect and promote these three pillars. Nevertheless, its scope of interest is very wide and includes not only human rights protection, democracy-building and combating challenges to the rule of law, but also biodiversity protection, challenges to sports, and youth and culture issues. Among this variety of interests and activities are some which are linked - directly or indirectly with the protection of the environment.

In this article, selected case law related to the environment from the European Court of Human Rights (ECtHR) and from the European Committee of Social Rights (ECSR), as well as the official publications of the $\mathrm{CoE}$ in this field will be outlined, to demonstrate its contribution to the climate change debate. Attention will also be paid to various texts relating to the above subject matter and revealing the real level of commitment of the organisation and its entities to the subject matter, mainly by the Committee of Ministers (CM), the Parliamentary Assembly of the Council of Europe (PACE), the Congress of Local and Regional Authorities (CLRA), and the CoE Human Rights Commissioner. Apart from that, references to the attempts to systematise the internal actions of the $\mathrm{CoE}$ bodies in the above field by establishing the Inter-secretariat Group on Climate Change will be included, in order to answer the question of whether the organisation has developed its own set of climate law standards. Subsequently, prospects and possibilities that arise from present achievements will be commented on.

One key observation is that the organisation acknowledges that climate change has become a very important issue and uses the environmental achievements it has already made to join the worldwide climate change de- 
bate. At the same time, it is apparent that the climatic subject matter is far from being central to the CoE's interests. As a result, the organisation does not play a standard-setting role in the field of climate law. Nevertheless, it undertakes certain actions to visualise its efforts; in particular, it proudly presents the case law of the ECtHR and the ECSR.

Having observed the above, it is anticipated that the trend to emphasise the environmental case law of the human rights protection bodies will continue. The author does not think that the organisation will be able to overcome its general reluctance to discuss climatic issues. Therefore, it is not expected that the $\mathrm{CoE}$ will soon become a key player in the worldwide debate that will contribute to the process of climate law standard-setting.

\section{A. Introduction}

Today, the Council of Europe $(\mathrm{CoE})$ consists of 47 member states which are home to approximately 800 million citizens. The organisation, founded on 5 May 1949 by ten countries, now covers virtually the entire European continent. It is said ${ }^{1}$ to seek to develop common and democratic principles throughout Europe, based on the European Convention on Human Rights (ECHR, the Convention) $)^{2}$ and other reference texts on the protection of individuals. ${ }^{3}$ In this article, it will be examined whether the $\mathrm{CoE}$ - the organisation anchored in the triad of human rights, democracy and the rule of law - has developed its own set of climate law standards. Subsequently, prospects and possibilities that arise from present achievements will be commented on. In particular, it is argued that anthropocentric perspectives

1 See http://www.coe.int/aboutCoe/index.asp?page=quisommesnous \&l=en; last accessed 15 December 2012.

2 Convention for the Protection of Human Rights and Fundamental Freedoms (1950) as amended by Protocols No. 11 (1994) and No. 14 (2004), ETS/CETS No.'s 005, 155 and 194.

3 Examples of such reference texts are recommendations of the Committee of Ministers (CM) or the Parliamentary Assembly of the Council of Europe (PACE), respectively, under Article 15 or Article 23 of the Statute of the Council of Europe (1949), ETS No. 001. According to Resolution No. 1 (1953) adopted by the Committee of Ministers at its 8 th Session, the conclusions of the Committee may, where appropriate, take the form of a convention or agreement. For the full list of treaties, see the official website of the CoE Treaty Office at http://conventions.coe.int/Treaty/Commun/ListeTraites. asp?CM=8\&CL=ENG, last accessed 15 December 2012. 
adopted by the organisation in fact self-limit the scope and impact of actions undertaken within the CoE.

\section{B. The Three Pillars}

As stated above, the CoE is based on the triad of human rights, democracy and the rule of law. ${ }^{4}$ In the author's opinion, the emphasis put on these common values by the $\mathrm{CoE}$ itself is apparent and seems to determine the organisation's range of activities. Therefore, the triad will be used as the starting point for the following text.

The triad of values may be treated as the common denominator in all actions taken within the $\mathrm{CoE}$. Some activities commonly associated with the $\mathrm{CoE}$ are, de facto, attributable to one of its statutory organs, i.e. a Council of Ministers (CM), consisting of the Ministers of Foreign Affairs, which usually meets at the level of their deputies, and the Parliamentary Assembly of the Council of Europe (PACE), which represents the political forces within the member states. ${ }^{5}$ Other actions associated with the CoE are actually performed by bodies established by the CM, such as the Congress of Local and Regional Authorities (CLRA), ${ }^{6}$ or are undertaken by statutory organs of the CoE's treaties, including the European Court of Human Rights (ECtHR $)^{7}$ and the European Committee of Social Rights (ECSR). ${ }^{8}$ Therefore, the subjective range and material scope of actions taken within the $\mathrm{CoE}$ which are associable with the notion of climate law are very wide. At the same time, it is not easy to indicate actions that would be devoted to climate without reference to the triad of values. In this regard, it should be pointed out that the capacity limitation of the present text does not allow to go too deeply into detail. Therefore, the actions taken by the statutory organs of the $\mathrm{CoE}$ will be indicated in principle. Selected activities by other organs and bodies will be highlighted, especially to mark the flow of ideas, standards and stipulations from one entity to another.

4 See the Statute of the Council of Europe, in particular the Preamble and Article 3.

5 See the Statute of the Council of Europe, in particular Article 10.

6 See the Statutory Resolution 94(3) of the Committee of Ministers of the Council of Europe establishing the Congress of Local and Regional Authorities.

7 See Section II of the ECHR regarding the ECtHR.

8 See Article 25 of the European Social Charter regarding the ECSR. 
The triad of values appears to divide the CoE's activities into three segments. At the same time, the values are so similar that it is not always easy to exactly match each activity with only one value. Therefore, to specify the appropriate value, it is advisable to analyse the budget of the CoE, its organisation, ${ }^{9}$ the arrangement of its Secretariat, the current terms of reference of its internal structures, ${ }^{10}$ and other relevant documents.

It might also be helpful to use the divisions applied on the CoE's website. ${ }^{11}$ In this regard, one may observe that the so-called climatic activities of the $\mathrm{CoE}$ are mostly performed under the following headings:

- Democracy, that is, PACE and CLRA activities

- Biodiversity, that is, activities relating to the European and Mediterranean Major Hazards Agreement and the Bern Convention on the Conservation of European Wildlife and Natural Habitats, and

- Human rights, that is, some aspects of jurisprudence of the ECtHR, development of human rights law and policy, and social rights guaranteed under the European Social Charter.

At the same time, one should take into account the structure of the Secretariat - the CoE's administrative body - which ensures that the organisation's various offices function properly and fulfil their mandates. In particular, it is noted that a clear division is made between the Directorate General of Human Rights and Rule of Law (DG I) on the one hand, and the Directorate General of Democracy (DG II) on the other. ${ }^{12}$ The above structure implies that the activities of DG I are derived either from the notion of human rights or from the concept of the rule of law, ${ }^{13}$ whereas DG II concentrates its work on the area of democracy. ${ }^{14}$

9 See Council of Europe Programme and Budget 2012-2013, pp 3, 223; available at https://wcd.coe.int/com.instranet.InstraServlet?command=com.instranet.CmdBlob Get\&InstranetImage $=1998892 \&$ SecMode $=1 \&$ DocId $=1838802 \&$ Usage $=2$, last accessed 15 December 2012.

10 See Terms of Reference of Intergovernmental Structures 2012-2013 of 23 November 2011 adopted by the CM, Ref. No. CM(2011)131 Final.

11 For the CoE website, see http://hub.coe.int/web/coe-portalaa, last accessed 15 December 2012.

12 See the CoE organisational charts published at http://www.coe.int/t/dgi/Organigram meDGI_EN.pdf and http://www.coe.int/t/DEMOCRACY/source/OrganisationChar t_DGII_en.pdf, last accessed 15 December 2012.

13 See, in particular, the structure of the Human Rights Directorate with the Secretariat of the European Committee for the Prevention of Torture and Inhuman or Degrading Treatment or Punishment (CPT), the Department for the Execution of Judgments of 
Summing up, the CoE examines climatic issues mostly under the headings Democracy and Human rights, which obviously correspond with the tasks of both DG I and DG II. Generally speaking, climate change is being discussed by various actors in different segments of the CoE's activities. Therefore, it is difficult to associate the climate law standard-setting mission with only one specific organ or body responsible for its further development and application. Nevertheless, the topic of climate change seems to be important enough to generate a need to link all the activities. In particular, a sort of inter-secretariat collaboration in this field has already been established in the shape of an Inter-secretariat Group on Climate Change. ${ }^{15}$ In the discussion that follows, a brief analysis of the 'climatic' actions taken by chosen actors on various levels of the CoE's structure will be provided in order to answer the question about climate law standards and the organisation's perspectives.

\section{Democracy}

As noted above, the vast majority of deliberations within the CoE concerning climatic issues take place under the heading of Democracy. In this regard, one may indicate two key actors: PACE (a statutory organ of the CoE) and the CLRA (established with the statutory resolution of the CM). The above forums are mainly platforms for exchanging views, and their standard-setting role in the field of climate law is not preponderant. Nevertheless, they do not hesitate to provide inspiration to other relevant organs, in particular the CM. In this respect, these two entities gradually call for the adoption of

the ECtHR, the Department of the European Social Charter and Social Security Code, the Human Rights Policy and Development Department, and the Bioethics Division, as well as the tasks of the Information Society and Action against Crime Directorate, the Justice and Human Dignity Directorate, and the Secretariat of the Enlarged Agreement on Democracy through Law (Venice Commission).

14 See, in particular, the structure of DG II, with the European Directorate for the Quality of Medicines and Healthcare; the Directorate of Democratic Citizenship and Participation; the Directorate of Democratic Governance, Culture and Diversity; and the Directorate of Human Rights and Anti-discrimination.

15 See the CoE website devoted to climate change, entitled Environment: Climate change, a threat to human rights, at http://hub.coe.int/what-we-do/culture-and-natu re/climate-change, last accessed 15 December 2012. 
new regulations in the field of environmental law. Therefore, an overview of their actions will be presented.

\section{Parliamentary Assembly of the Council of Europe}

PACE is a forum for debate for parliamentarians from all over Europe and represents the political forces (majority and opposition) within the $\mathrm{CoE}$ member states. It can adopt three different types of texts: recommendations, resolutions and opinions. ${ }^{16}$ PACE recommendations contain proposals addressed to the CM, the implementation of which is within the competence of governments. PACE decisions on questions which it is empowered to put into effect, or expressions of view for which it alone is responsible, take the form of resolutions. PACE also expresses opinions, mostly on questions put to it by the CM. ${ }^{17}$

PACE contains, inter alia, the Committee on the Environment, Agriculture and Local and Regional Affairs. This Committee resulted from a merger that took place in 2001 between the Committee on the Environment, Regional Planning and Local Authorities and the Committee on Agriculture, Rural Development and Food. The Committee on the Environment, Regional Planning and Local Authorities, which was established in 1952 as a special body on municipal and regional affairs, became a general committee of the Assembly in 1956. The subject of "Environment" was added to the Committee's title in $1986 .{ }^{18}$ This Committee seems to be concerned with the issue of climate change, and stimulates the debate about climate change within PACE. Among the Committee's recent actions is that, in 2011, it issued a Declaration on climate change entitled "As the world's warmest year ends, time for climate change to be seen as a human rights issue". ${ }^{19}$ In this Declaration, the Committee called on the CoE to hold a major transversal conference on "human rights and climate change" to discuss the connections

16 Article 23(a) of the Statute of the Council of Europe.

17 See also http://assembly.coe.int/Main.asp?link=/AboutUs/APCE_Procedure.htm, last accessed 15 December 2012.

18 See the PACE Resolution 1425 (2005) on revising the terms of reference of Assembly Committees.

19 See the Declaration of the PACE Committee on the Environment, Agriculture and Local and Regional Affairs on Climate Change of 27 January 2011; available at http://www.assembly.coe.int/Communication/270111_declarationclimate_E.pdf, last accessed 15 December 2012. 
between climate change and human rights in Europe, and whether human rights obligations could strengthen international policy in the field of climate change. ${ }^{20}$

Apparently, since the late 1980s, PACE - aware of the environmental challenges facing the planet - has urged for action in various texts, as follows:

- Resolution 919 (1989) on the Destruction of Tropical Forests - Causes and Remedies

- Resolution 926 (1989) on the Danger of Climatic Changes and the Protection of the Ozone Layer

- Recommendation 1130 (1990) on the Formulation of a European Charter and a European Convention on Environmental Protection and Sustainable Development

- Recommendation 1140 (1991) on Global Environmental Change and the Role of Science and Democracy

- Order 458 (1991) on Climate Change: This invites its Committee on Science and Technology to study scientific and technological measures to minimise climate change and to make recommendations on policy options to stabilise global climate

- Resolution 987 (1992) on Climate Change: This was subsequently adopted, calling on member states to implement certain policy responses to the above phenomenon, such as to -

- encourage international cooperation and legal instruments

- stabilise carbon dioxide emissions at their 1990 level by 2000

- review and adjust energy policies and programmes

- promote energy conservation and energy efficiency

- promote energy production methods and fossil fuels that emit less carbon dioxide

- review the development of nuclear power in the light of waste and safety problems

- promote research on clean energy and nuclear safety

- promote research, development and demonstration of renewable and other sustainable energy sources

- review aid and technology transfer programmes to developing countries

- promote reforestation and care of forests

20 (ibid.). 
- encourage research into the reduction of carbon dioxide emissions by road traffic

- promote international monitoring and coordination on climate change issues

- enhance scientific research, and

- improve information transfer to policymakers.

A decade later, the Assembly was mostly occupied by the challenges and possibilities presented by the Kyoto Protocol to the United Nations Framework Convention on Climate Change (UNFCCC). In its Resolution 1243 (2001) on the Kyoto Protocol on Climate Change: Need for Committed International Solidarity, PACE concentrated on expressing its total support for putting the Kyoto Protocol into practice. Subsequently, it adopted Resolution 1250 (2001) and its Recommendation 1520 (2001) on the technological possibilities for fulfilling the targets of the Kyoto Protocol. In both texts, PACE gave specific advice on how to achieve the Kyoto goals, and emphasised the importance of pro-climatic actions. Additionally, it expressed its further support in -

- Resolution 1292 (2002) on the World Summit on Sustainable Development: Ten Years after Rio

- Recommendation 1594 (2003) on the Follow-up to the World Summit on Sustainable Development: A Common Challenge, and

- Resolution 1406 (2004) on Global Warming: Beyond Kyoto.

The above texts were followed by its Resolution 1552 (2007) on the Capture of Carbon Dioxide as a Means of Fighting Climate Change, in which PACE welcomed the entry into force of the Kyoto Protocol on 16 February 2005 and called for further actions. Subsequently, in its Recommendation 1883 (2009) and Resolution 1682 (2009) on the challenges posed by climate change, the Assembly urged $\mathrm{CoE}$ member and observer states to negotiate an ambitious integrated package as part of the new global climate change agreement. Then, in Recommendation 1918 (2010) on Biodiversity and Climate Change, PACE recommended that the CM call on the governments of $\mathrm{CoE}$ member and observer states to take into account the opportunities offered by the International Year of Biodiversity in 2010.

It is also important to emphasise PACE's activities outside the CoE. In particular, attention should be devoted to the outcome paper issued by the Inter-parliamentary Union (of which PACE is an associate member), together with the Mexican Congress, with the support of the United Nations 
Development Programme (UNDP) on the occasion of the 16th Conference of the Parties to the UNFCCC and the 6th Meeting of the Parties to the Kyoto Protocol (COP16/CMP6) in Cancún, Mexico, on 6 December 2010. In the said outcome paper, parliamentarians from all over the world called on the Inter-parliamentary Union to pursue its efforts to mobilise the global parliamentary community around the issue of climate change. ${ }^{21}$

At $\mathrm{CoE}$ level, PACE has also issued many texts committed to protecting the environment ${ }^{22}$ which are thematically related to the issue of climate change. Among these texts, it is worth mentioning Recommendation 1885

21 See the Outcome Document of 6 December 2010 adopted by the Parliamentary Meeting on the Occasion of the United Nations Climate Change Conference, Cancún (Mexico); available at http://www.ipu.org/splz-e/cop16/final.pdf, last accessed 15 December 2012.

22 To mention the texts pronounced in the last decade alone, these are Resolution 1869 (2012) on the Environmental Impact of Sunken Shipwrecks; Resolution 1851 (2011) on Armed Conflicts and the Environment; Resolution 1815 (2011) on the Potential Dangers of Electromagnetic Fields and their Effect on the Environment; Resolution 1794 (2011) on Preserving the Environment in the Mediterranean; Resolution 1775 (2010) on Military Waste and the Environment; Recommendation 1946 (2010) on Military Waste and the Environment; Recommendation 1885 (2009) on Drafting an Additional Protocol to the European Convention on Human Rights concerning the Right to a Healthy Environment; Recommendation 1879 (2009) on Renewable Energies and the Environment; Recommendation 1863 (2009) on Environment and Health: Better Prevention of Environment-related Health Hazards; Resolution 1655 (2009) on Environmentally Induced Migration and Displacement: A 21st Century Challenge; Recommendation 1862 (2009) on Environmentally Induced Migration and Displacement: a 21st Century Challenge; Recommendation 1837 (2008) on the Fight against Harm to the Environment in the Black Sea; Resolution 1596 (2008) on Protection of the Environment in the Arctic Region; Resolution 1588 (2007) on Radioactive Waste and Protection of the Environment; Resolution 1542 (2007) on Electronic Waste and the Environment; Resolution 1461 (2005) on the Curonian Spit, Oil and the Environment; Resolution 1449 (2005) on the Environment and the Millennium Development Goals; Resolution 1435 (2005) on Energy Systems and the Environment; Recommendation 1689 (2004) on Hunting and Europe's Environmental Balance; Recommendation 1653 (2004) on Environmental Accounting as a Sustainable Development Tool; Recommendation 1637 (2003) on Pan-European Environmental Co-operation: The Council of Europe's Role after the Kyiv Ministerial Conference and the Johannesburg Summit; Recommendation 1614 (2003) on Environment and Human Rights; Resolution 1296 (2002) on the Change of Name of the Committee on the Environment and Agriculture to Committee on the Environment, Agriculture and Local and Regional Affairs; Resolution 1295 (2002) on the State of the Environment of the Baltic Sea; and Recommendation 1571 (2002) on Reducing Environmental Risks by Destroying Chemical Weapons. 
(2009) on Drafting an Additional Protocol to the European Convention on Human Rights Concerning the Right to a Healthy Environment. ${ }^{23}$ In this Recommendation, PACE noted, inter alia, the case law in the environmental field developed by the ECtHR. In PACE's view, the above case law had afforded protection for the right to a healthy environment through a 'knockon effect', by upholding the individual rights in Articles 2 and 8 of the European Convention on Human Rights (ECHR). In this regard, PACE recommended that the CM draw up an Additional Protocol to the Convention, recognising the right to a healthy and viable environment.

In this regard, it is noteworthy that the reply from the CM of 19 June 2010 to Recommendation 1883 (2009) on the Challenges Posed by Climate Change, and to Recommendation 1885 (2009) on Drafting an Additional Protocol to the European Convention on Human Rights Concerning the Right to a Healthy Environment, may be perceived as moderate. ${ }^{24}$ The only

23 The close relation between the above Recommendation and the subject matter of climate change is reflected by the fact that the CM decided to give its joint reply to PACE's Recommendation 1883 (2009) on the Challenges Posed by Climate Change, and to PACE's Recommendation 1885 (2009) on Drafting an Additional Protocol to the European Convention on Human Rights Concerning the Right to a Healthy Environment. See Reply of 19 June 2010 to the Recommendation 1883 (2009) on the Challenges Posed by Climate Change, and to the Recommendation 1885 (2009) on Drafting an Additional Protocol to the European Convention on Human Rights Concerning the Right to a Healthy Environment, CM/Cong(2010)Rec271-281 Final.

24 In particular, with regard to climate change, the CM pointed out that climate change may have implications regarding the enjoyment of universally recognised fundamental rights. It also underlined the global scope of challenges posed by climate change and suggested that, should the priorities and the resources of the CoE so permit, a conference be held to examine the issue from various angles, e.g. human rights and legal affairs, the environment, and social cohesion. Finally, it found it appropriate to refer to the appended comments of the Committee of Senior Officials of the CoE CM responsible for Spatial/Regional Planning, the Committee of Permanent Correspondents of the European and Mediterranean Major Hazards Agreement, and the Standing Committee of the Bern Convention, which outline aspects of their work relevant to this issue. At the same time, with regard to PACE Recommendation 1885 (2009) on Drafting an Additional Protocol to the European Convention on Human Rights Concerning the Right to a Healthy Environment, the CM adopted a similar position to its replies to Recommendation 1614 (2003) on the Environment and Human Rights, and Recommendation 1862 (2009) on Environmentally Induced Migration and Displacement: A 21 st Century Challenge. In the above replies, the $\mathrm{CM}$ did not consider it advisable to draw up an Additional Protocol to the Convention in the environmental domain. At the same time, the CM recalled that PACE Recommendation 1614 (2003) had led to the preparation by the Steering 
two real actions envisaged by the $\mathrm{CM}$ at that time were to consider the possibility of holding a conference on climate change and human rights, and to continue works on updating and extending the 2006 Manual on Human Rights and the Environment ${ }^{25}$ in the light of the case law of the ECtHT and the ECSR, of relevant standards set out by other international organisations, and of good practices adopted at national level. ${ }^{26}$ This temperate reaction of the $\mathrm{CM}$ is typical in this category of matters. More generally, one may notice the usually proactive character of PACE Resolutions and Recommendations, contrasting with the more balanced replies given at governmental level by the $\mathrm{CM}$.

In this regard, it should be stressed that PACE texts have no binding effect on either the member states or the CM, and are merely of an opinion-making and advisory nature. It is also not easy to establish to what extent they reflect the political moods present in the governments and parliaments of Europe. This is because parliamentarians appointed to PACE represent various political forces of their member states, as a requirement exists for a balance of political parties within each national delegation. Therefore, PACE texts may principally be considered as a very interesting voice in the discussion on the European response to climate change phenomenon and the challenges it implies, and may be invoked at various forums. Nevertheless, due to the nonbinding character of the texts issued by PACE, as well as the specific way in which PACE delegations are elected, the above voice has no decisive impact on the final solutions adopted at governmental level.

Committee for Human Rights (CDDH, Comité Directeur pour les Droits de l'Homme) of a Manual on Human Rights and the Environment: Principles emerging from the case-law of the European Court of Human Rights in 2006, and had taken note of the agreement within the $\mathrm{CDDH}$, within the framework of the Committee of Experts for the Development of Human Rights (DH-DEV), to update and extend the Manual, in the light of, notably, the case law of the ECtHR and of the ECSR, of relevant standards set out by other international organisations, and of good practices adopted at national level, in order to give effect to the principles emerging from the ECtHR's case law. Finally, the CM referred to the substantial work already carried out by the $\mathrm{CoE}$ in the field of the environment, which has led to the adoption of important legal instruments such as the Convention on the Conservation of European Wildlife and Natural Habitats (ETS No. 104), the Convention on Civil Liability for Damage resulting from Activities Dangerous to the Environment (ETS No. 150) and the Convention on the Protection of the Environment through Criminal Law (ETS No. 172).

25 CoE (2006).

26 Reply from the CM of 19 June 2010. 


\section{Congress of Local and Regional Authorities}

As mentioned above, the present CLRA is not one of the statutory bodies of the organisation, anchored directly in the Statute of the Council of Europe, but was established on 14 January 1994 by way of Statutory Resolution 94(3) of the CM. It is a consultative organ composed of representatives of local and regional authorities. ${ }^{27}$ Its main role is to evaluate the application of the European Charter of Local Self-government and to support the improvements of governance of local and regional authorities. ${ }^{28}$

In a similar way to PACE, the CLRA also pays attention in its texts to the issue of climate change by way of recommendations and resolutions. ${ }^{29}$ Three pairs of the most important of these issued since 2009 should be mentioned, namely -

- Recommendation 271 (2009) and Resolution 288 (2009) on the Global Challenge of Climate Change: Local Responses ${ }^{30}$

- Recommendation 281 (2010) and Resolution 298 (2010): After Copenhagen, Cities and Regions take up the Challenge, ${ }^{31}$

- Recommendation 298 (2010) and Resolution 317 (2010): Coastal Towns and Cities tackling Threats from the Sea. ${ }^{32}$

The above texts call for purposive actions in the respective areas and emphasise the need to engage local and/or regional authorities. ${ }^{33}$ As is the case

27 See Article 1 of the CM Statutory Resolution CM/Res(2011)2 relating to the Congress of Local and Regional Authorities of the Council of Europe and the revised charter appended thereto.

28 (ibid.:Article 2).

29 As with PACE texts, CLRA Recommendations include proposals addressed to the $\mathrm{CM}$ for implementation by governments. They may also be addressed to other international organisations. Resolutions refer to authorities of local and/or regional character, as well as to their associations. For further details, see the CLRA website at http://www.coe.int/t/congress/texts/adopted-texts_en.asp?mytabsmenu=6, last accessed 15 December 2012.

30 Dated 14 October 2009.

31 Dated 18 March 2010.

32 Dated 28 October 2010.

33 It is said that "for the Congress, action against climate change must go beyond reduction of greenhouse gas emissions and the use of renewable energy sources. It is also a question of good governance and the right to a healthy environment". See again the $\mathrm{CoE}$ website devoted to climate: Environment: Climate change, a threat to human rights. 
with PACE Recommendations, CLRA Recommendations are not legally binding instruments. Furthermore, the replies from the CM to the climatic recommendations of the CRLA are as temperate as the replies to those of PACE. ${ }^{34}$ In particular, the joint reply to the CLRA Recommendations 271 (2009) and 281 (2010) include reference to the reply of the CM to PACE Recommendations 1883 (2009) and 1885 (2009) on the Challenges Posed by Climate Change and on Drafting an Additional Protocol to the European Convention on Human Rights Concerning the Right to a Healthy Environment. ${ }^{35}$ As already pointed out, to date the outcome of the above PACE Recommendations at governmental level has been quite moderate.

The character of the CLRA implies that the meaning of its Recommendations and Resolutions is comparable to those of PACE. They may be treated as a very interesting voice in the discussion. Nevertheless, their impact on governmental activities remains limited. At the same time, one should emphasise a very unique feature of the CLRA texts: they all stress the need to engage local and/or regional authorities in activities concerning climate change.

\section{Other Environmental Work}

Apart from the work of PACE and the CLRA, the substantial work already carried out by the $\mathrm{CoE}$ in the field of the environment is worth mentioning, which has resulted in the adoption of significant legal instruments such as the Convention on the Conservation of European Wildlife and Natural Habitats (Bern Convention), ${ }^{36}$ the Convention on Civil Liability for Damage resulting from Activities Dangerous to the Environment, ${ }^{37}$ and the Convention

34 See the CM Reply of 16 June 2010 to CLRA Recommendation 271 (2009): The Global Challenge of Climate Change: Local Responses, as well as Recommendation 281 (2010): After Copenhagen, Cities and Regions take up the Challenge, Ref. No. CM/Cong(2010)Rec271-281 Final. See also the CM Reply of 7 December 2011 to CLRA Recommendation 298 (2011): Coastal Towns and Cities tackling Threats from the Sea, Ref. No. CM/Cong(2011)Rec298 Final.

35 See in particular para. 3 of the CM Joint Reply of 16 June 2010.

36 Convention on the Conservation of European Wildlife and Natural Habitats (1979), ETS No. 104.

37 Convention on Civil Liability for Damage Resulting from Activities Dangerous to the Environment (1993), ETS No. 150. 
on the Protection of the Environment through Criminal Law. ${ }^{38}$ The subject matter of the above international treaties is linked with the issue of climate change. In this regard, particularly the Bern Convention, comes to mind, which $\_39$

... implements on the European continent the UN Convention on Biological Diversity ... sets European standards in environmental policies related to biodiversity and bio security ... [and] aims at the protection and sustainable use of Europe's biological diversity through a monitoring mechanism.

As stated earlier, for the purpose of the present text it is not intended to go into the details of the Bern Convention. As pointed out earlier, the objective of this article is to review the actions undertaken by the statutory organs of the $\mathrm{CoE}$ and to augment them by way of information regarding works of other bodies within the $\mathrm{CoE}$. Therefore, as regards this particular point, attention should be drawn to the achievements of the Group of Experts on Biodiversity and Climate Change ${ }^{40}$ under Article 14 of the Bern Convention.

The Group of Experts on Biodiversity and Climate Change was set up at the 26th Meeting of the Standing Committee of the Bern Convention. ${ }^{41}$ The purpose of creating this Group was to "provide guidance to Parties on understanding climate change impacts and threats, and developing appropriate adaptation measures in national policies regarding the species and habitats protected under the Bern Convention." 42

38 Convention on the Protection of the Environment through Criminal Law (1998), ETS No. 172.

39 See Council of Europe Programme and Budget 2012-13, 128.

40 The Group of Experts on Biodiversity and Climate Change is one of the expert groups subordinated to the Standing Committee of the Bern Convention. Presently, nine such groups exist, namely on the Conservation of Amphibians and Reptiles - Marine Turtles; the Conservation of Plants; the Conservation of Birds; the Conservation of Invertebrates; Protected Areas and Ecological Networks; Invasive Alien Species; Large Carnivores; Biodiversity and Climate Change; and European Island Biological Diversity. See also the Bern Convention website at http://www.coe.int/t/dg4/cultur eheritage/nature/experts_EN.asp, last accessed 15 December 2012.

41 See the report on the 26th Meeting of the Standing Committee of the Convention on the Conservation of European Wildlife and Natural Habitats of 27-30 November 2006, Ref. No. T-PVS(2006)24E, 11 December 2006, and the Group's Terms of Reference accessible under "Draft Programme of Activities for 2007 of Standing Committee of the Bern Convention adopted at the 26th Meeting on 27-30 November 2006", Ref. No. T-PVS(2006)14, 8 .

42 See the Terms of Reference (ibid.). 
The Group has already conducted seven general meetings as well as one special meeting. ${ }^{43}$ The results of the Group's work consist of various Recommendations on biodiversity and climate change adopted by the Standing Committee, ${ }^{44}$ namely -

- Recommendation 159 (2012) on the Effective Implementation of Guidance for Parties on Biodiversity and Climate Change

- Recommendation 158 (2012) on Conservation Translocations under Changing Climatic Conditions

- Recommendation 152 (2011) on Marine Biodiversity and Climate Change

- Recommendation 147 (2010) on Guidance for Parties on Wildland Fires, Biodiversity and Climate Change

- Recommendation 146 (2010) on Guidance for Parties on Biodiversity and Climate Change in European Islands

- Recommendation 145 (2010) on Guidance for Parties on Biodiversity and Climate Change in Mountain Regions

- Recommendation 143 (2009) on Further Guidance for Parties on Biodiversity and Climate Change

- Recommendation 142 (2009) on Interpreting the CBD Definition of Invasive Alien Species to take into Account Climate Change

- Recommendation 135 (2008) on Addressing the Impacts of Climate Change on Biodiversity, and

- Recommendation 122 (2006) on the Conservation of Biological Diversity in the Context of Climate Change.

Having indicated the above long list of Recommendations, it can be observed that the link between the subject matter of the Bern Convention and climate

43 The meetings took place on 14-15 June 2007 (1st Meeting of the Group of Experts); on 12 October 2007 (Select Committee on Biodiversity and Climate Change); on 13-14 March 2008 (2nd Meeting of the Group of Experts); on 11-12 September 2008 (3rd Meeting of the Group of Experts); on 2-3 July 2009 (4th Meeting of the Group of Experts); on 21-23 June 2010 (5th Meeting of the Group of Experts); on 10-11 October 2011 (6th Meeting of the Group of Experts); and on 1-2 October 2012 (7th Meeting of the Group of Experts). See the Bern Convention website, as well as relevant meeting reports placed therein, at http://www.coe.int/t/dg4/culture heritage/nature/experts_EN.asp, last accessed 15 December 2012.

44 For the texts of Recommendations, see the Bern Convention website at http://www .coe.int/t/dg4/cultureheritage/nature/Bern/recommendations_en.asp, last accessed 15 December 2012. 
change is quite evident. Nevertheless, it seems to me that it is the subject matter of the Bern Convention that needs to take into account the changing climatic conditions, rather than the other way around. To be more precise, the Bern Convention is, in principle, a tool for biodiversity conservation. Therefore, any attempts at its implementation make no sense without considering the local circumstances such as climate. At the same time, application of the above treaty may have little or no effect on the process of climate change; or, at the very least, the prevention or slowing down of climate change was not the purpose the drafters had in mind. ${ }^{45}$

\section{Human Rights}

As already stated, there are deliberations relating to climate law within the $\mathrm{CoE}$ that take place under the heading of human rights. In this regard, the case law of human rights protection bodies, but also the work of other bodies and organs based on that case law are of particular relevance.

\section{Case Law of Human Rights Protection Bodies}

In discussing human rights protection bodies, the 'environmental dimension' of jurisprudence of the ECtHR needs to be focussed. Taking into account certain other developments, specific findings by the ECSR are also considered.

Both the ECtHR and the ECSR were designed to judge whether states parties are in conformity in law and in practice with the provisions of the human rights treaties - the ECHR and Additional Protocols to the ECHR, ${ }^{46}$ or the European Social Charter, respectively. Therefore, it should

45 The aims of the Bern Convention are to conserve wild flora and fauna and natural habitats, to promote cooperation between states, and to give particular attention to endangered and vulnerable species, including endangered and vulnerable migratory species. See Explanatory Report to the Convention on the Conservation of European Wildlife and Natural Habitats (ETS No. 104); available at http://www.conventions. coe.int/Treaty/en/Reports/Html/104.htm, last accessed 15 December 2012.

46 See again the ECHR. See also the Protocol to the Convention for the Protection of Human Rights and Fundamental Freedoms (1952), ETS No. 009; Protocol No. 4 to the Convention for the Protection of Human Rights and Fundamental Freedoms, Securing Certain Rights and Freedoms other than those Already Included in the 
first be emphasised that neither the Convention nor the Charter guarantees the right to a healthy environment as such. Indeed, it is also difficult to think of the above human rights protection instruments as being able to prevent or stop climate change. Nevertheless, it is now indisputable that the gradual evolution of jurisprudence by the ECtHR has resulted in the recognition of environmental human rights, ${ }^{47}$ mostly in connection to Article 8 of the Convention, which provides a right to respect for one's "private and family life". ${ }^{48}$ The above tendency was followed by the ECSR. .9

The existing case law of the ECtHR seems to be significant for the overall work of the CoE. In particular, it is often treated as a starting point for further deliberations by various bodies and organs. To emphasise its meaning, the appropriate set of references to the jurisprudence of the human rights protection bodies was collected by government experts from CoE member states and published in 2006 as the Manual on Human Rights and the Environment. ${ }^{50}$ One may also observe the ECtHR's own proactiveness, which aims to promote the link between human rights and the environment. To strengthen the effect of the dissemination of knowledge and to stress the considerable scale of the ECtHR's achievements, in January 2012, the ECtHR Registry decided to issue a fact sheet on environment-related cases in the ECtHR's case law and to publish it on the ECtHR website. ${ }^{51}$ Thanks to the above

Convention and in the First Protocol Thereto (1963), ETS No. 046; Protocol No. 6 to the Convention for the Protection of Human Rights and Fundamental Freedoms Concerning the Abolition of the Death Penalty (1983), ETS No. 114; Protocol No. 7 to the Convention for the Protection of Human Rights and Fundamental Freedoms (1984), ETS No. 117; Protocol No. 12 to the Convention for the Protection of Human Rights and Fundamental Freedoms (2000), ETS No. 177; and Protocol No. 13 to the Convention for the Protection of Human Rights and Fundamental Freedoms, Concerning the Abolition of the Death Penalty in all Circumstances (2002), ETS No. 187.

47 See the Council of Europe Commissioner for Human Rights Viewpoint of 19 October 2009, entitled "Climate change is causing an unprecedented, global human rights crisis - and must now be countered by co-ordinated, rights-based action", by Thomas Hammarberg; available at http://www.coe.int/t/commissioner/viewpoints/091019 EN.asp?, last accessed 15 December 2012.

48 See the case law of the ECtHR, referred to below.

49 See the case law of the ECSR, referred to below; see also the findings under Article 11 of the European Social Charter.

$50 \operatorname{CoE}(2006,2012)$.

51 See Factsheet - Environment-related Cases in the Court's Case Law, available at http://www.echr.coe.int/ECHR/en/Header/Press/Information+sheets/Factsheets/, last accessed 15 December 2012. 
efforts, it is not difficult to indicate the ECtHR case law concerning airport noise, ${ }^{52}$ neighbouring noise; ${ }^{53}$ industrial pollution posing a danger to people's health ${ }^{54}$ industrial pollution posing other adverse effects on the environment; ${ }^{55}$ deforestation and urban development; ${ }^{56}$ and passive smoking. ${ }^{57}$ Of course, the above indication is illustrative, not exhaustive. It covers cases in which the ECtHR has found the violation of 'environmental' human rights $^{58}$ and the ones where no such violation was found. ${ }^{59}$

Similar efforts were made with regard to the environmental findings of the ECSR. In 2008, the Case Law Digest ${ }^{60}$ was published, presenting the interpretation that the ECSR had made of the various Articles of the Euro-

52 See Powell \& Raynerv United Kingdom, Application No. 9310/81, ECtHR judgment of 21 February 1990; See Hatton v United Kingdom, Application No. 36022/97, ECtHR judgment (GC) of 8 July 2003.

53 See Moreno Gomez v Spain, Application No. 4143/02, ECtHR judgment of 16 November 2004; DEÉS v Hungary, Application No. 2345/06, ECtHR judgment of 9 November 2010; Mileva \& Others v Bulgaria, Application No.'s 43449/02 and 21475/04, ECtHR judgment of 25 November 2010; Dubetska \& Others $v$ Ukraine, Application No. 30499/03, ECtHR judgment of 10 February 2011; Zammit Maempel \& Others $v$ Malta, Application No. 24202/10, ECtHR judgment of 22 November 2011.

54 See Öneryıldiz v Turkey, Application No. 48939/99, ECtHR judgment (GC) of 30 November 2004; Lopez Ostra $v$ Spain, Application No. 16798/90, ECtHR judgment of 9 December 1994; Fadeyeva v Russia, Application No. 55723/00, ECtHR judgment of 9 June 2005; Giacomelliv Italy, Application No. 59909/00, ECtHR judgment of 2 November 2006; Guerra \& Others v Italy, Application No. 14967/89, ECtHR judgment of 19 February 1998; Taşkın \& Others v Turkey, Application No. 46117/99, ECtHR judgment of 10 November 2004.

55 See Tatar v Romania, Application No. 657021/01, ECtHR judgment of 27 January 2009; l'Erablière v Belgium, Application No. 49230/07, ECtHR judgment of 24 February 2009; Mangouras v Spain, Application No. 12050/04, ECtHR judgment (GC) of 28 September 2010; Di Sarno \& Others v Italy, Application No. 30765/08, ECtHR judgment of 10 January 2012.

56 See Hamer v Belgium, Application No. 21861/03, ECtHR judgment of 27 November 2007; Kyrtatos v Greece, Application No. 41666/98, ECtHR judgment of 22 May 2003.

57 See Florea v Romania, Application No. 37186/03, ECtHR judgment of 14 September 2010.

58 For example, DEÉS v Hungary, Mileva \& Others v Bulgaria.

59 For example, Powell \& Rayner $v$ United Kingdom and Hatton v United Kingdom.

60 See the Case Law Digest of the European Committee of Social Rights; available at http://www.coe.int/t/dghl/monitoring/socialcharter/Digest/DigestSept2008_en.pdf, last accessed 15 December 2012. 
pean Social Charter. ${ }^{61}$ The Digest, under the heading of "The right to enjoy the highest possible standard of health attainable" (Article 11 of the Charter), contains a whole section on healthy environment, with subsections on food safety, nuclear hazards for communities living in the vicinity of nuclear power plants, risks relating to asbestos, and air pollution. It contains references to the ECSR's findings in the cases International Federation of Human Rights Leagues (FIDH) v France ${ }^{62}$ and Marangopoulos Foundation for Human Rights (MFHR) v Greece. ${ }^{63}$

Other CoE bodies commonly refer to these environmental judgments and decisions in order to support their own position and/or activities in the field of 'environmental' human rights. In this regard, once again PACE's Recommendation 1885 (2009) on Drafting an Additional Protocol to the European Convention on Human Rights Concerning the Right to a Healthy Environment needs to be highlighted. ${ }^{64}$ In the above text, PACE referred directly to "case law in the environmental field developed by the European Court of Human Rights" as well as to the Manual on Human Rights and the Environment, ${ }^{65}$ which serves as a guide to the Strasbourg case law. The author would also like to add a reference to the viewpoint of the CoE Commissioner for Human Rights of 19 October 2009 entitled "Climate change is causing an unprecedented, global human rights crisis - and must now be countered by coordinated, rights-based action", by the then Commissioner Thomas Hammarberg. ${ }^{66}$ In the author's opinion, the Commissioner's viewpoint, based on the references to ECtHR and ECSR case law, illustrates the way in which the majority of environment-related texts are being structured

61 See information note at http:/www.coe.int/t/dghl/monitoring/socialcharter/Digest/ DigestIndex_en.asp, last accessed 15 December 2012.

62 See International Federation of Human Rights Leagues (FIDH) v France, Complaint No. 14/2003, ECSR decision on the merits, of 3 November 2004, para. 31.

63 See Marangopoulos Foundation for Human Rights (MFHR) v Greece, Complaint No. 30/2005, ECSR decision on the merits, of 6 December 2006, para.'s 194-202.

64 See again the PACE Recommendation 1885 (2009) on Drafting an Additional Protocol to the European Convention on Human Rights Concerning the Right to a Healthy Environment, referred to above.

65 CoE (2006).

66 Thomas Hammarberg was CoE Commissioner for Human Rights from 1 April 2006 to 31 March 2012; see biographical note at http://www.coe.int/t/commissioner/Offi ce/prevCommissioners_en.asp, last accessed 7 February 2012. 
within the CoE. He invoked ECtHR case law ${ }^{67}$ and emphasised that European human rights standards and principles envisaged safeguards which needed to be integrated into plans and policies to address climate change. The Commissioner also provided a short analysis of ECtHR findings, and observed that, according to the latter's case law, severe environmental pollution could affect the well-being of individuals and prevent them from enjoying their homes in such a way as to adversely affect their private and family life. ${ }^{68} \mathrm{He}$ noted that the ECtHR had confirmed the obligation of states to conduct proper studies before allowing an activity which could cause environmental damage, and to bring such studies to the attention of the public. ${ }^{69}$ Furthermore, he indicated that the ECtHR had found a violation of the right to life in a case where the authorities had not taken preventive action when they had been aware of an increased risk of large-scale mudslides and had not informed the population of the risk..$^{70} \mathrm{He}$ also emphasised that the European Social Charter provided for the right to health, on the basis of which the ECSR had held states responsible for showing measurable progress in lowering levels of pollution. ${ }^{71}$ In addition, he stated that the same ruling would cover nuclear hazards as well as risks related to asbestos and food safety. ${ }^{72}$

\section{Development of Human Rights Law and Policy}

As far as the development of human rights law and policy is concerned, a brief comment on the work at governmental level by the Steering Committee for Human Rights (CDDH, Comité Directeur pour les Droits de l'Homme)

67 The Commissioner invoked Lopez Ostra v Spain, para. 51; Taşkın \& Others v Turkey; and Budayeva \& Others v Russia, Application No. 15339/02, judgment 29 September 2008.

68 See Lopez Ostra v Spain, para. 51.

69 See Taşkin \& Others $v$ Turkey.

70 See Budayeva \& Others v Russia.

71 See Marangopoulos Foundation for Human Rights (MFHR) v Greece, Complaint No. 30/2005, ECSR decision on the merits, of 6 December 2006, para.'s 203 and 205.

72 See CoE Commissioner for Human Rights Viewpoint. 
should be made, ${ }^{73}$ followed subsequently by the work executed by the CM. To do this, it is necessary to note again that the principal role of the $\mathrm{CDDH}$, under the auspices of the CM, is "to set up standards commonly accepted by the 47 Member States with the aim of developing and promoting human rights in Europe and improving the effectiveness of the control mechanism established by the European Convention on Human Rights."74

It can be seen that climate change is not situated in the centre of interests of either the $\mathrm{CDDH}$ or the $\mathrm{CM}$. At present, the standard-setting role of the said Steering Committee in the field of climate law is quite narrow, as the $\mathrm{CDDH}$ is willing to undertake activities solely of a promotional nature.

A fine and relatively current illustration of the above approach is contained in the CDDH Opinion on PACE Recommendation 1883 (2009) on the Challenges Posed by Climate Change. ${ }^{75}$ In this Opinion, the CDDH reiterates the position adopted in its comments to Recommendation 1614 (2003) on the Environment and Human Rights, ${ }^{76}$ which is that neither the ECHR nor its Additional Protocols expressly recognise a right to the protection of the environment. At the same time, it noted that the ECHR system had already indirectly contributed to the protection of the environment through existing Convention rights and their interpretation in ECtHR case law. Consequently, the CDDH did not consider it advisable to draft an Additional Protocol to the Convention on the suggested topic. Nonetheless, it expressed its support for the idea to pursue studies on the subject at intergovernmental level by means of regular exchanges of views within the framework of the Committee of Experts for the Development of Human Rights (DH-DEV) and by updating and extending the 2006 Manual on Human Rights and the Environment, in the light of the jurisprudence of the

73 The CDDH was set up by the CM under Article 17 of the Statute of the Council of Europe, and operates in accordance with Resolution CM/Res(2011)24 on intergovernmental committees and subordinate bodies, their terms of reference, and their working methods.

74 See the CDDH home page available at http://www.coe.int/t/dghl/standardsetting/cd dh/default_en.asp, last accessed 15 December 2012. See also the CDDH Terms of Reference set up by the CM under Article 17 of the Statute of the Council of Europe and in accordance with Resolution CM/Res(2011)241 on intergovernmental committees and subordinate bodies, their terms of reference and working methods.

75 CDDH Opinion on PACE Recommendation 1883 (2009) - The Challenges Posed by Climate Change, Ref. No. CDDH(2009)019.

76 CDDH Opinion on PACE Recommendation 1614 (2003) on Environment and Human Rights, Ref. No. CDDH(2003)026. 
ECtHR, of the ECSR, of relevant standards set out by other international organisations, and of good practices adopted at national level. The CDDH also noted the possibility, subject to available funding, of holding a conference to examine the issue of climate change from various angles, e.g. human rights and legal affairs, the environment, and social cohesion. If so, it expressed its availability to contribute to this work through the DH-DEV.

The above Opinion illustrates the CDDH's general approach of refraining from deep engagement into establishing new, legally binding human rights standards in the field of protection of the environment. It is notable that the $\mathrm{CDDH}$ concentrates on promoting the existing standards inferred from already adopted international treaties. In particular, the $\mathrm{CDDH}$ decided that it would be appropriate to make more explicit the protection indirectly afforded by the ECHR to the environment by updating the 2006 Manual. In the CDDH's view, such an approach would be "a useful way of promoting greater awareness in member states of the implications of their existing obligations under the Convention in environmental matters." 77

As it transpires from the previous submissions under Subsection I above, the CM subsequently shared the $\mathrm{CDDH}$ position. The $\mathrm{CM}$ expressed its attitude towards the above idea in its reply of 19 June 2010 to Recommendation 1883 (2009) on the Challenges Posed by Climate Change, and to Recommendation 1885 (2009) on Drafting an Additional Protocol to the European Convention on Human Rights Concerning the Right to a Healthy Environment.

\section{Environmental Activities of the CoE}

The above short review of recent selected activities of the CoE indicates that the environmental achievements of the organisation are not significant. Its main environmental accomplishment in the latter half of 2012 was the updating of the 2006 Manual on Human Rights and the Environment. One may also point out similar actions, such as the publication of the relevant Factsheet on the ECtHR website, and of the Digest on the ECSR website. In this context, it is possible to note a general, visible trend to disseminate and promote the already existing 'environmental' human rights standards. Nev-

77 Final Activity Report of the CDDH on Human Rights and Environment of 29 November 2005, Ref. No. CDDH(2005)016, Addendum II, para. 2. 
ertheless, the $\mathrm{CoE}$ is talking about human rights, human rights perspectives, human rights standards, and a human rights environmental dimension. The link between the above standards and the issue of climate change is not direct. In particular, the primary aim of the jurisprudence collected in the Manual, the Digest and the relevant Factsheet was not to combat climate change, but to provide an adequate response to human rights violations. In this regard only the general individualistic and anthropocentric approach of the human rights protection bodies to the above-mentioned challenges will be emphasised.

As regards the Manual itself, attention should be paid to the overall process of its preparation. The $\mathrm{CDDH}$ received the terms of reference to draft the Manual from the CM in a decision dated 21 January $2004 .{ }^{78}$ The CDDH entrusted this task to a subordinate intergovernmental body of experts, namely the DH-DEV. The Manual was published in $2006 .{ }^{79}$ In 2009 , the CM decided ${ }^{80}$ on the said PACE Recommendation 1885 (2009) ${ }^{81}$ to update the Manual, and it was duly published in $2012 .{ }^{82}$ Apart from activities aimed to increase the public understanding of the relationship between the European system of human rights protection and the environment, some internal coordination work was done within the CoE. In particular, the Inter-secretariat Group on Climate Change was established, which represents many different entities and sectors of the $\mathrm{CoE}$ and serves the purpose of exchanging information and discussing possible common initiatives. ${ }^{83}$ In other words, it improves the flow of information within different $\mathrm{CoE}$ entities. It appears that meetings of the Inter-secretariat Group took place on 11 February 2011, 17 March 2011, 30 May 2011, 5 July 2011, 6 February 2012 and 16 March $2012 .{ }^{84}$ The deliberations within this Group resulted in the establishment of a climate change $\mathrm{CoE}$ website, which contains the most relevant documentation by the organisation on climate change, and is capable of acting as a knowledge base. ${ }^{85}$ The Group has also been responsible for examining the

78 See CM Reply of 23 January 2004 on PACE Recommendation 1614 (2003) on the Environment and Human Rights, Ref. No. CM/AS(2004)Rec1614 Final.

79 See CoE (2006).

80 See Document CDDH(2009)019, para. 19.

81 See again the PACE Recommendation 1885 (2009).

82 See CoE (2012).

83 See CoE website.

84 (ibid.).

85 (ibid.). 
possibility of organising the above-mentioned conference to explore the relationship between climate change and human rights in Europe.

Thus far, the discussions concerning a possible conference have not led to concrete results. It was first scheduled for 2012 but was then postponed - largely due to budgetary and organisational constraints. ${ }^{86}$ Nevertheless, there seems to be consensus at the level of the Inter-secretariat Group, at least, that such a conference is necessary and will be useful. The conference is also perceived as an opportunity to raise awareness in the $\mathrm{CM}$ about climate change. Furthermore, it is expected to act as a catalyst for building on the valuable work on climate change being carried out in different parts of the organisation. ${ }^{87}$

\section{Standards and Perspectives}

As is shown by the above discussion, the achievements of the CoE in the field of climate law standards are modest. The organisation has not developed any legally binding instrument that could be exclusively devoted to the issue of climate change. In fact, it is due only to the creativity of various bodies and organs that the existing legal texts have been linked with climate change. As a result, certain achievements regarding the protection of the environment and/or human rights are now being used as a starting point for further climatic deliberations.

In this regard, the actions taken under the heading Biodiversity (Bern Convention-related actions within the Pillar of Democracy) have to be distinguished from other deliberations around the subject of Human rights (within the Pillar of Human Rights and/or Democracy). As stated above, in the case of the Biodiversity segment, the link between the subject matter of the Bern Convention and climate change is quite evident. Nevertheless, one should be reluctant to name the above treaty as a source of the climate law and standards. ${ }^{88}$ Also, the various climatic recommendations of the Standing Committee of the Bern Convention seem to be technical tools for accurate

86 The conference was initially planned for 2012. It was subsequently decided to postpone it until 2013. See 7th Inter-secretariat Group on Climate Change Meeting Report of 6 February 2012 [unpublished].

87 (ibid.:4).

88 As has already been stated, the author perceives the Bern Convention primarily as a nature-preservation instrument. 
implementation of the above treaty rather than a source of climate law as such.

At the opposite extreme, there is a range of human rights treaties, such as the ECHR, Additional Protocols to the ECHR, and the European Social Charter. In this respect, it is important to remember that -89

... [n] either the European Convention on Human Rights nor the European Social Charter protects the environment as such, but various individual rights provided for in these treaties which might be affected by the environment. Hence, it is rather the impact on the individual than the environment that both the Court and the Committee are concerned with.

The above anthropocentric perspective makes the present European system of human rights protection an incommodious tool for developing climate law standards. One may notice that the already existing case law of the human rights protection bodies is always retrospective and involves an element of individual rights violation (the victim status), which is also harmful to the environment (e.g. noise pollution, industrial pollution or passive smoking). In this regard, environmental rights protection under the Convention and the Charter is merely fragmentary. Only a few cases ${ }^{90}$ may be directly linked to the issue of climate change. Due to this fact, as well as the subject matter involved, the author is not convinced that existing or future case law may play a decisive role in establishing climate law standards on a regional or global scale. In particular, it seems unlikely that the system, which is individual-complaint-oriented, would be the best possible tool to combat pollution, biodegradation and climate change. Such an advocacy may play an auxiliary and not a leading role in the process of standard-setting.

The above insufficiency was already noticed by PACE, which called for the adoption of a new human rights treaty in the form of an Additional Protocol to the European Convention on the Protection of the Environment. As it transpires from the reply of the CM referred to above, the idea did not gain support at governmental level. It resulted merely in updating the 2006 Manual. The internal discussion about the possible organisation of a conference on human rights and climate change at the level of the $\mathrm{CoE}$ is still pending.

It is apparent that the issue of climate change was never a priority for the $\mathrm{CM}$. Also, at least until now, the $\mathrm{CDDH}$ has not given priority to this issue in its future planning. It seems that climate law has been perceived more as

$89 \operatorname{CoE}(2012: 16)$.

90 For example, Budayeva \& Others v Russia, from 2008. 
a global issue that should be discussed from a worldwide perspective at the UN level rather than from a European perspective. ${ }^{91}$ At the same time, the topic itself seems to be important enough to command the attention of various bodies and organs within the $\mathrm{CoE}$, such as PACE, the CLRA and the Human Rights Commissioner. In this regard, further multiplication of environmental case law of the human rights protection bodies is to be expected. Furthermore, actions aiming to present and promote the principles flowing from existing case law can be anticipated. Nevertheless, it seems rather unlikely that the organisation becomes a key player that would contribute to the process of climate law standard-setting in the worldwide debate at any time soon.

\section{References}

Alston, Philip, Ryan Goodman \& Hennry J. Steiner, 2007, International Human Rights in Context: Law, Politics, Morals (Third Edition), Oxford, Oxford University Press.

Alfredsson, Gudmundur, 2010, Human Rights and the Environment, in: Leary, David \& Balakrishna Pisupati (Eds), The Future of International Environmental Law, New York/Paris/Tokyo, United Nations University Press, 127-146.

Anton, Donald K. \& Dinah L. Shelton, 2011, The Environment and Human Rights, Cambridge, Cambridge University Press.

Birnie, Patricia, Alan Boyle \& Catherine Redgwell, 2009, International Law and the Environment (Third Edition), Oxford, Oxford University Press.

Boyle, Alan, 2010, Human Rights and the Environment: A Reassessment, United Nations Environment Programme Paper 2010 (Revised), available at http://www.unep.org/en vironmentalgovernance/Portals/8/documents/Events/HumanRightsEnvironmentRev .pdf, last accessed 7 February 2013.

Bodansky, Daniel, Jutta Brunnee \& Elle Hey, 2008, The Oxford Handbook of International Environmental Law, Oxford, Oxford University Press.

CoE/Council of Europe, 2006, Manual on Human Rights and the Environment: Principles Emerging from the Case-law of the European Court of Human Rights, Strasbourg, Council of Europe Publishing.

CoE/Council of Europe, 2012, Manual on Human Rights and the Environment (Second Edition), Strasbourg, Council of Europe Publishing.

91 For similar opinions, see the 7th Inter-secretariat Group on Climate Change Meeting Report of 6 February 2012, 2. 
Déjeant-Pons, Maguelonne \& Marc Pallemaerts (Eds), 2002, Human Rights and the Environment: Compendium of Instruments and other International Texts on Individual and Collective Rights Relating to the Environment in the International and European Framework, Strasbourg, Council of Europe Publishing.

Francioni, Francesco, 2010, International Human Rights in an Environmental Horizon, European Journal of International Law 21, 41-55.

Fitzmaurice, Malgosia, 2011, The European Court of Human Rights, Environmental Damage and the Applicability of Article 8 of the European Convention on Human Rights and Fundamental Freedoms, Environmental Law Review 13 (2), 107-114.

García San José, Daniel, 2005, Environmental Protection and the European Convention on Human Rights, Human Rights Files No. 21, Strasbourg, Council of Europe Publishing.

Glazebrook, Susan, 2009, Human Rights and the Environment, Victoria University of Wellington Law Review 40 (1), 293-351.

Gouritin, Armelle, 2011, Potential Liability of European States under the ECHR for Failure to take Appropriate Measures with a View to Adaptation to Climate Change, Institute for European Studies (IES) Commune Workshop, "Environmental Law", 27 November 2009, in: Faure, Michael \& Marjan Peeters (Eds), Climate Change Liability, Cheltenham, Edward Elgar Publishing, 134-162.

Loucaides, Loukis, 2005, Environmental Protection through the Jurisprudence of the European Convention on Human Rights, British Yearbook of International Law 75, 249-267.

MacDonald, Karen E., 2008, A Right to a Healthful Environment-Humans and Habitats: Re-thinking Rights in an Age of Climate Change, European Energy and Environmental Law Review 17 (4), 213-226.

Pallemaerts, Marc, 2008, A Human Rights Perspective on Current Environmental Issues and Their Management: Evolving International Legal and Political Discourse on the Human Environment, the Individual and the State, Human Rights and International Legal Discourse 2, 149-178.

Pallemaerts, Marc, 2009, Human Rights and Sustainable Spatial Development, in: Proceedings of the International CEMAT Symposium on "The Spatial Dimension of Human Rights: For a New Culture of the Territory", Yerevan, Armenia, 13-14 October 2008, European Spatial Planning and Landscape Series, No. 91, Strasbourg, Council of Europe Publishing, 45, 61; also available at www.coe.int/t/dg4/cultureheritage/he ritage/Landscape/Publications/ATEP-91Assemble_bil.pdf, last accessed 7 February 2013.

Pedersen, Ole W., 2008, European Environmental Human Rights and Environmental Rights: A Long Time Coming?, Georgetown International Environmental Law Review 21, 73-111.

Pedersen, Ole W., 2010, The Ties that Bind: The Environment, the European Convention on Human Rights and the Rule of Law, European Public Law 16 (4), 571-595.

Schall, Christian, 2008, Public Interest Litigation Concerning Environmental Matters Before Human Rights Courts: A Promising Future Concept?, Journal of Environmental Law 20, 417-453. 
Shelton, Dinah L., 2010a, Developing Substantive Environmental Rights, Journal of Human Rights and the Environment 1, 89-120.

Shelton, Dinah L., 2010b, International Decision: Tâtar v Romania, American Journal of International Law 104, 247-252.

Trilsch, Mirja, 2009, European Committee of Social Rights: The Right to a Healthy Environment, International Journal of Constitutional Law 7, 529-538. 